\title{
FAKTOR-FAKTOR YANG MEMENGARUHI INTENSI BERWIRAUSAHA GENERASI MILENIAL DI JAKARTA
}

\author{
Millenia Setiawan ${ }^{1}$, Frangky Slamet ${ }^{2}$ \\ ${ }^{1}$ Program Studi Manajemen, Fakultas Ekonomi dan Bisnis, Universitas Tarumanagara \\ Email: millenia.115180308@stu.untar.ac.id \\ ${ }^{2}$ Program Studi Manajemen, Fakultas Ekonomi dan Bisnis, Universitas Tarumanagara* \\ Email: frangkys@fe.untar.ac.id \\ *Penulis Korespondensi
}

Masuk : 15-01-2022, revisi: 20-01-2022, diterima untuk diterbitkan : 25-01-2022

\begin{abstract}
ABSTRAK
Pendidikan kewirausahaan adalah sebuah proses yang bertujuan untuk memicu individu dalam berwirausaha dengan cara memberikan ilmu pengetahuan, keahlian dan keterampilan yang berhubungan dengan kreatifitas dan pengenalan peluang untuk penciptaan usaha baru. Kemudian, modal finansial adalah bentuk sumber daya yang diperlukan sebagai alat transaksi dalam memulai kegiatan usaha untuk mencapai hasil yang diinginkan. Penelitian ini bertujuan untuk mengetahui pengaruh pendidikan kewirausahaan dan modal finansial terhadap intensi berwirausaha dengan metode kuantitatif yang berjenis konklusif dan cross-sectional design. Dalam penelitian ini, data diperoleh secara online dengan menggunakan google form, yang dikirimkan melalui Whatsapp, Instagram, dan Line terhadap 90 responden yang merupakan generasi milenial dan berdomisili di Jakarta dengan metode nonprobability sampling (convenience sampling). Kemudian, terdapat 2 (dua) hipotesis dalam penelitian ini yang dianalisis menggunakan PLS-SEM dengan software Smart Partial Least Square 3.0. Hasil penelitian ini menunjukkan bahwa pendidikan kewirausahaan dan modal finansial masing-masing memiliki pengaruh yang positif dan signifikan terhadap intensi berwirausaha generasi milenial di Jakarta.
\end{abstract}

Kata Kunci: Pendidikan Kewirausahaan, Modal Finansial, Intensi Berwirausaha

\begin{abstract}
Entrepreneurship education is a process that aim to trigger individuals in entrepreneurship by providing knowledge, expertise and skills related to creativity and the introduction of opportunities for the creation of new businesses. Then, financial capital is a form of resources needed as a transaction tool in starting business activities to achieve the desired results. This study aims to determine the effect of entrepreneurship education and financial capital on entrepreneurial intentions with conclusive quantitative methods and cross-sectional design. In this study, data was obtained online using a google form, which was sent via Whatsapp, Instagram, and Line to 90 respondents who are millennials and live in Jakarta using the non-probability sampling method (convenience sampling). Then, there are 2 (two) hypotheses in this study which were analyzed using PLS-SEM with Smart Partial Least Square 3.0 software. The results of this study indicate that entrepreneurship education and financial capital each have a positive and significant influence on the entrepreneurial intention of the millennial generation in Jakarta.
\end{abstract}

Keywords: Entrepreneurship Education, Financial Capital, Entrepreneurial Intention

\section{PENDAHULUAN \\ Latar Belakang}

Intensi berwirausaha telah menarik perhatian selama bertahun-tahun (Linan \& Fayolle, 2015). Intensi berwirausaha seorang individu ditunjukkan oleh kesiapannya untuk mengabdikan diri dengan sepenuh hati untuk bisnisnya, tingkat intensi yang lebih tinggi untuk memulai suatu usaha, komitmen untuk memulai suatu perusahaan dan semangat untuk menjadi seorang wirausaha (Echchabi, Omar \& Ayedh, 2020). 
Studi mengungkapkan bahwa intensi berwirausaha individu dipengaruhi oleh sejumlah faktor mulai dari karakteristik kepribadian hingga faktor lingkungan (Santos, Roomi \& Linan, 2016). Banyak penelitian yang telah menemukan bahwa pendidikan kewirausahaan, yang merupakan faktor lingkungan, saat ini diakui menjadi hal dasar sebagai modal pengetahuan dan keterampilan bisnis yang dapat membantu individu untuk memulai bisnisnya dan tentunya hal ini menunjukkan bahwa pendidikan kewirausahaan memiliki dampak terhadap intensi berwirausaha (Hahn, Minola, Van Gils \& Huybrechts, 2017). Sementara menurut Ozaralli dan Rivenburgh (2016) modal finansial juga sering dikaitkan dengan tantangan dalam intensi berwirausaha, karena modal finansial tentunya memengaruhi penciptaan usaha baru dengan inovasi dan teknologi. Penelitian ini berfokus kepada generasi milenial. Generasi milenial adalah sebutan untuk generasi yang lahir pada tahun 1980-2000 (Wei-Loon, 2013). Generasi milenial berperan sebagai pelopor ide-ide kreatif dan inovatif yang dibutuhkan dalam menciptakan hal baru di masyakarat (Gaddefors \& Anderson, 2017).

Sehubungan dengan adanya latar belakang permasalahan di atas, maka dilakukan penelitian ini untuk mengamati dan mencermati pendidikan kewirausahaan dan modal finansial berpengaruh terhadap intensi berwirausaha generasi milenial di Jakarta.

\section{Gambaran Umum Teori}

Theory of Planned Behavior menjadi teori dasar acuan yang digunakan dalam penelitian ini. Menurut Ajzen (1991), dalam memahami dan memprediksi intensi individu Theory of Planned Behavior (TPB) mengklasifikasikan pembentukan sebuah intensi individu ke dalam 3 (tiga) kategori yang diantaranya yaitu fungsi dari sikap terhadap perilaku, norma subjektif sosial pada keinginan perilaku, dan kontrol perilaku yang dirasakan.

Menurut Theory of Planned Behavior (TPB) sikap terhadap perilaku adalah penilaian seseorang tentang dampak dari perilaku yang diinginkan (baik atau buruk, menguntungkan atau tidak menguntungkan). Di sisi lain, norma subjektif mengacu pada persepsi kelompok sosial yang penting bagi orang itu (sebagai tekanan sosial) dan memengaruhi tentang melakukan perilaku yang dimaksudkan (Ajzen, 1991). Akhirnya, kontrol perilaku yang dirasakan adalah persepsi individu tentang kemudahan atau kesulitan melakukan perilaku yang diinginkan (Ajzen, 1991).

\section{Definisi Konseptual Variabel}

Menurut Hockerts (2018, h. 237) intensi berwirausaha dideskripsikan sebagai "willingness of individuals, to perform the behaviour of an entrepreneur, to engage in entrepreneurial action, to be self-employed and to establish new business." Intensi berwirausaha seorang individu ditunjukkan oleh kesiapannya untuk mengabdikan diri dengan sepenuh hati untuk bisnisnya (Echchabi et al., 2020).

Definisi pendidikan kewirausahaan menurut Hynes (2006, h. 12) adalah "the process or series of activities which aim to enable an individual to assimilate and develop knowledge, skills, values and understanding that are not simply related to a narrow field of activity." Berdasarkan uraian tersebut, dapat dikatakan bahwa pendidikan kewirausahaan adalah sebuah proses yang bertujuan untuk memicu intensi berwirausaha individu dengan cara memberikan ilmu pengetahuan, keahlian dan keterampilan yang berhubungan dengan kreatifitas dan pengenalan peluang untuk penciptaan usaha baru.

Adapun menurut Da Cruz (2018, h. 376) modal finansial diartikan sebagai "economic resources in this case are in the form of money needed by individuals or companies to finance the needs 
that will be allocated to start running a new business, which is expected to achieve the desired goals for success." Modal finansial berperan sebagai bahan bakar yang mendorong intensi dalam kegiatan berwirausaha, terutama dalam proses awal memulai bisnis (Fisch, 2019).

\section{Kaitan Pendidikan Kewirausahaan dan Intensi Berwirausaha}

Pendidikan kewirausahaan dianggap sebagai ukuran penting untuk mendorong aktivitas kewirausahaan dengan mengembangkan intensi berwirausaha individu (Tanazha \& Budiono, 2021). Penelitian yang dilakukan oleh Daniel dan Handoyo (2021) membuktikan bahwa terdapat pengaruh positif dan signifikan antara pendidikan kewirausahaan dengan intensi berwirausaha.

\section{Kaitan Modal Finansial dan Intensi Berwirausaha}

Berdasarkan kebutuhan sebuah usaha, modal finansial mutlak dibutuhkan untuk memulai sebuah proses kegiatan usaha. Setiap individu pasti membutuhkan modal finansial atau biaya untuk dapat mengoperasikan bisnisnya (Kew, Herrington, Litovsky \& Gale, 2013). Berdasarkan penelitian yang dilakukan Hasliza, Abu dan Muhammad (2020) ditemukan bahwa dukungan modal finansial memengaruhi secara positif dan signifikan terhadap intensi berwirausaha.

Berdasarkan hal yang telah dijabarkan di atas, maka ditetapkan hipotesis penelitian ini sebagai berikut:

H1: Pendidikan kewirausahaan berpengaruh positif dan signifikan terhadap intensi berwirausaha generasi milenial di Jakarta.

H2: Modal Finansial berpengaruh positif dan signifikan terhadap intensi berwirausaha generasi milenial di Jakarta.

Untuk lebih jelasnya, berikut adalah model penelitian yang dijelaskan pada Gambar 1.

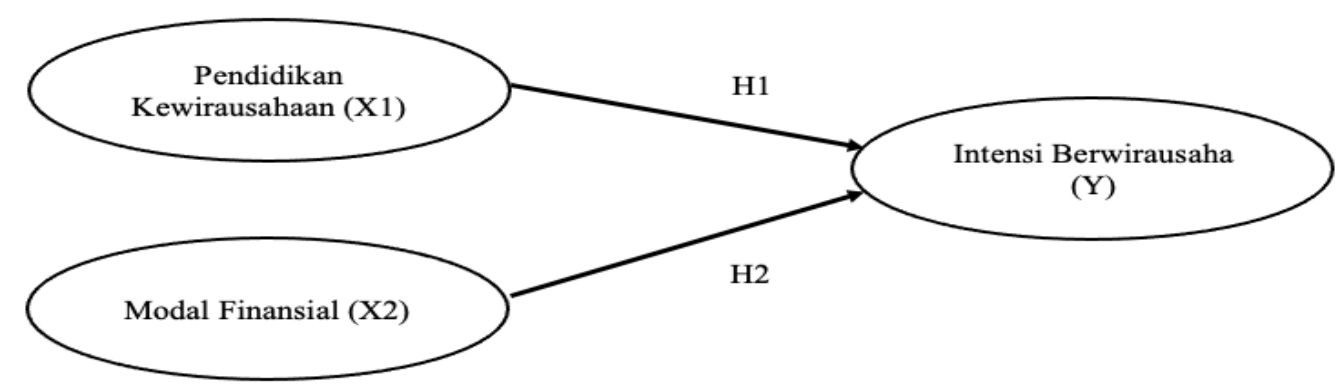

Gambar 1. Model penelitian

\section{METODE PENELITIAN}

Pada penelitian ini desain penelitian yang digunakan adalah penelitian konklusif. Penelitian konklusif terbagi menjadi 2 (dua) kategori yaitu deskriptif dan kausal. Penelitian ini menggunakan jenis deskriptif, yang bertujuan untuk memberikan deskripsi atau gambaran guna untuk menjelaskan variabel-variabel yang terkait dalam penelitian. Penelitian ini menggunakan metode cross-sectional design sebagai metode dalam mengumpulkan data.

Populasi dalam penelitian ini adalah generasi milenial yang memiliki rentang usia 21-41 tahun di Jakarta. Sampel diambil menggunakan teknik non-probability sampling dengan pendekatan convenience sampling dengan ukuran sampel 90 responden. Dari 90 responden, mayoritas adalah berjenis kelamin wanita sejumlah 58 responden (64\%). Kemudian, mayoritas responden dalam penelitian ini memiliki latar belakang pendidikan terakhir adalah SMA/SMK sejumlah 69 responden (77\%). Selanjutnya, mayoritas responden adalah pelajar/mahasiswa sejumlah 58 responden (64\%). Mayoritas responden lahir di tahun 2000 sejumlah 62 responden (69\%). 
Berdasarkan data yang diperoleh, mayoritas responden dalam penelitian ini berdomisili di Jakarta Barat sejumlah 46 responden $(51 \%)$. Adapun mayoritas responden dalam penelitian ini memiliki latar belakang pekerjaan orang tua sebagai wirausaha sejumlah 61 responden $(68 \%)$.

Pengumpulan data menggunakan kuesioner yang diberikan nilai atau skor Skala Likert 1-5. Analisis data menggunakan PLS-SEM yang diolah menggunakan software Smart Partial Least Square 3.0. Tahap pertama adalah pengujian outer model yang digunakan untuk menguji validitas dan reliabilitas. Analisis validitas diukur dengan memerhatikan nilai loading factor > 0,5 (Ghozali \& Latan, 2014) dan nilai AVE > 0,5 (Hair, Risher, Sarstedt \& Ringle, 2019). Selanjutnya dengan memerhatikan nilai Cross Loading di mana nilai korelasi indikator ke variabel latennya harus lebih besar dari nilai indikator ke variabel laten lainnya (Garson, 2016). Selain itu dengan memerhatikan juga nilai Fornell-Larcker yang diukur dengan memerhatikan nilai dari akar kuadrat AVE suatu variabel dan biasanya lebih besar dari nilai korelasi antar variabel laten lainnya (Henseler, Ringle \& Sinkovics, 2009). Pengukuran reliabilitas dengan melihat nilai Cronbach's Alpha (CA) dan Composite Reliability (CR). Nilai CA dan CR yang baik harus lebih dari 0.6 (> 0.6) untuk dinyatakan reliabel (Hair et al., 2019).

Tahap Kedua adalah dengan pengujian inner model. Pertama adalah dengan analisis $R$-Square $\left(\mathrm{R}^{2}\right)$. Rentang nilai $\mathrm{R}^{2}$ dikategorikan menjadi kuat dengan nilai minimal 0,670 , sedang dengan nilai minimal 0,330, dan lemah dengan nilai minimal 0,190 (Henseler et al., 2009). Kedua adalah dengan analisis Predictive Relevance. Apabila nilai predictive relevance di atas 0 (nol), maka dapat dikatakan model memiliki nilai predictive relevance yang baik. Sebaliknya, apabila nilai di bawah 0 (nol), mengartikan bahwa model tidak memiliki nilai predictive relevance yang baik (Hair, Ringle \& Sarstedt, 2011).

Ketiga adalah dengan analisis effect size $\left(\mathrm{f}^{2}\right)$. Analisis effect size terbagi menjadi 3 (tiga) kategori yaitu variabel eksogen memiliki efek yang kecil terhadap variabel endogen apabila nilai $\mathrm{f}^{2}$ dengan rentang 0,020-0,140, efek yang sedang dengan rentang 0,141-0,340, dan efek yang kuat apabila di atas 0,340 (Hair et al., 2019). Keempat adalah dengan analisis Goodness of Fit (GoF). Nilai terkecil dalam pengukuran ini adalah 0,100 . Jika nilainya 0,250 maka dinyatakan sedang, dan nilai 0,360 dinyatakan memiliki nilai yang besar (Tennehaus, 2004). Terakhir adalah dengan menguji hipotesis. Dalam menguji hipotesis, dapat dilihat dari nilai pada $t$-statistic dan $p$-value. Batas minimal untuk $t$-statistic adalah 1,96 dan nilai $p$-value harus lebih kecil dari 0,05 untuk dapat diterima. Selain itu, dilakukan juga analisis path coefficients yang digunakan untuk mengukur pengaruh jalur dalam model. Nilai dari uji path coefficients ini berkisar dalam rentang -1 hingga 1 yang mengidentifikasikan variabel memiliki pengaruh yang positif atau negatif (Hair et al., 2019).

\section{HASIL DAN PEMBAHASAN Analisis Validitas}

Berdasarkan hasil dari analisis validitas yang dilakukan, diketahui bahwa seluruh variabel dalam penelitian ini memperoleh nilai AVE dan loading factor di atas 0,5 yang dapat diartikan bahwa semua variabel dalam penelitian ini valid. Selain itu, analisis validitas dengan memerhatikan nilai Cross Loading dan Fornell-Larcker dalam penelitian ini sudah memenuhi kriteria sehingga dapat dikatakan bahwa instrumen penelitian ini valid.

\section{Analisis Reliabilitas}

Berdasarkan hasil dari analisis reliabilitas yang dilakukan, diketahui bahwa penelitian ini sudah memenuhi kriteria karena nilai CA dan CR setiap variabel dalam penelitian ini yaitu pendidikan 
kewirausahaan (X1), modal finansial (X2), dan intensi berwirausaha (Y) sudah di atas 0,6 (>0,6) sehingga dapat disimpulkan bahwa instrumen penelitian ini reliabel.

\section{Analisis Konstruk Penelitian}

Berdasarkan hasil dari analisis $\mathrm{R}^{2}$ dijelaskan bahwa nilai $\mathrm{R}^{2}$ dari intensi berwirausaha sebesar 0,451. Hal ini mengartikan bahwa 45,1\% variabel intensi berwirausaha dapat dipengaruhi oleh variabel pendidikan kewirausahaan dan modal finansial. Kemudian berdasarkan hasil dari analisis predictive relevance, dijelaskan bahwa hasil analisis menunjukkan bahwa nilai $\mathrm{Q}^{2} \mathrm{di}$ atas 0 (nol) yaitu sebesar 0,276 . Hal ini mengartikan bahwa variabel pendidikan kewirausahaan dan modal finansial memiliki predictive relevance yang baik terhadap variabel intensi berwirausaha. Berdasarkan hasil dari analisis effect size, diketahui bahwa nilai $\mathrm{f}^{2}$ dari variabel pendidikan kewirausahaan sebesar 0,400 (efek kuat). Di sisi lain, nilai $\mathrm{f}^{2}$ dari variabel modal finansial sebesar 0,144 (efek sedang).

Selanjutnya adalah berdasarkan analisis perhitungan nilai GoF, penelitian ini dapat dikatakan memiliki tingkat kelayakan yang besar yaitu 0,719. Terakhir adalah berdasarkan dengan pengujian hipotesis yang dilakukan, dapat dikatakan bahwa seluruh variabel eksogen dalam penelitian ini memiliki pengaruh yang positif dan signifikan terhadap variabel endogen. Untuk lebih jelasnya, dirangkum pada Tabel 1 di bawah ini.

Tabel 1. Hasil Pengujian Hipotesis

\begin{tabular}{|c|c|c|c|c|c|}
\hline Kode & Hipotesis & Path Coefficients & t-statistic & p-value & Keterangan \\
\hline H1 & $\begin{array}{c}\text { Pendidikan Kewirausahaan } \rightarrow \text { Intensi } \\
\text { Berwirausaha }\end{array}$ & 0,502 & 4,938 & 0,000 & Diterima \\
\hline H2 & Modal Finansial $\rightarrow$ Intensi Berwirausaha & 0,301 & 3,668 & 0,000 & Diterima \\
\hline
\end{tabular}

\section{Diskusi}

Berdasarkan hasil dari penelitian ini, hipotesis pertama yaitu pendidikan kewirausahaan memiliki pengaruh yang positif dan signifikan terhadap intensi berwirausaha individu yang secara khusus adalah generasi milenial di Jakarta diterima. Penelitian ini juga sejalan dan mendukung penelitian lain yang dilakukan oleh Daniel dan Handoyo (2021) juga membuktikan terdapat pengaruh positif dan signifikan antara pendidikan kewirausahaan dengan intensi berwirausaha. Pendidikan kewirausahaan memberikan kontribusi untuk meningkatkan kepercayaan diri individu, yang selanjutnya mendorong intensi berwirausaha (Linan, Santos \& Fernandez, 2011).

Selanjutnya, hipotesis kedua yaitu modal finansial memiliki pengaruh yang positif dan signifikan terhadap intensi berwirausaha individu yang secara khusus adalah generasi milenial di Jakarta juga diterima. Hasil dari penelitian ini sejalan dengan penelitian yang dilakukan oleh Hasliza et al. (2020) ditemukan bahwa dukungan modal finansial memengaruhi secara positif dan signifikan terhadap intensi berwirausaha. Berdasarkan kebutuhan sebuah usaha, modal finansial mutlak dibutuhkan untuk memulai sebuah proses kegiatan usaha. Setiap individu pasti membutuhkan modal finansial atau biaya untuk dapat mengoperasikan bisnisnya (Kew et al., 2013).

\section{KESIMPULAN DAN SARAN}

Berdasarkan hasil dari penelitian yang telah dilakukan, dapat disimpulkan bahwa pendidikan kewirausahaan dan modal finansial memiliki pengaruh yang positif dan signifikan terhadap intensi berwirausaha generasi milenial di Jakarta. Keterbatasan dalam penelitian ini adalah faktor-faktor yang diteliti dalam memengaruhi intensi berwirausaha hanya terbatas kepada 2 
(dua) variabel. Selanjutnya, populasi dalam penelitian ini tidak diketahui secara jelas dan akurat jumlah dan keberadaannya, serta keterbatasan waktu.

Berdasarkan pemaparan di atas, maka disarankan untuk penelitian selanjutnya pengambilan sampel dan variabel diharapkan lebih banyak serta ruang lingkup domisili diperluas sehingga data yang diperoleh dari responden lebih bervariasi serta dapat mewakili populasi.

\section{REFERENSI}

Ajzen, I. (1991). The theory of planned behavior. Organizational Behavior and Human Decision Processes, 50(2), 179-211.

Da Cruz, J. V. (2018). Beyond financing: crowdfunding as an informational mechanism. Journal of Business Venturing, 33(3), 371-393.

Daniel., \& Handoyo, S. E. (2021). Pengaruh Pendidikan Kewirausahaan, Lingkungan, dan Motivasi Berwirausaha Terhadap Intensi Berwirausaha Mahasiswa. Jurnal Manajemen dan Kewirausahaan, 3(4), 944-952.

Echchabi, A., Omar, M. M. S., \& Ayedh, A. M. (2020). Entrepreneurial intention among female university students in Oman. Journal for International Business and Entrepreneurship Development, 12(4), 280-297.

Fisch, C. (2019). Initial coin offerings (ICOs) to finance new ventures. Journal of Business Venturing, 34(1), 1-22.

Garson, G. D. (2016). Partial Least Squares: Regression \& Structural Equation Models. North Carolina: Statistical Associates Publishing.

Gaddefors, J., \& Anderson, A. R. (2017). Entrepreneursheep and context: when entrepreneurship is greater than entrepreneurs. International Journal of Entrepreneurial Behavior \& Research, 23(2), 267-278.

Ghozali, I., \& Latan, H. (2014). Structural equation modeling, metode alternatif dengan Partial Least Square (PLS). Edisi 4. Semarang: Badan Penerbit Universitas Diponegoro.

Hair, J. F., Ringle, C. M., \& Sarstedt, M. (2011). PLS-SEM Indeed a silver bullet. The Journal of Marketing Theory and Practice, 19(2), 139-151.

Hair, J. F., Risher, J. J., Sarstedt, M., \& Ringle, C. M. (2019). When to use and how to report the results of PLS-SEM. European Business Review, 31(1), 2-24.

Hahn, D., Minola, T., Van Gils, A., \& Huybrechts, J. (2017). Entrepreneurial education and learning at universities: exploring multilevel contingencies. Entrepreneurship and Regional Development, 29(9), 945-974.

Hasliza, H., Abu, B. S., \& Muhammad, S. R. (2020). Shaping entrepreneurial intention among youngsters in Malaysia. Journal of Humanities and Applied Social Sciences, 2(3), 235-251.

Henseler, J., Ringle, C. M., \& Sinkovics, R. R. (2009). The Use of Partial Least Squares Path Modeling In International Marketing. New Challenges to International Marketing Advances in International Marketing, 20, 277-319.

Hockerts, K. (2018). The effect of experiential social entrepreneurship education on intention formation in students. Journal of Social Entrepreneurship, 9(3), 234-256.

Hynes, B. (2006). Entrepreneurship education and training: introducing entrepreneurship into non-business disciplines. Journal of European Industrial Training, 20(8), 10-17.

Tanazha, J., \& Budiono, H. (2021). Pengaruh Pendidikan Kewirausahaan, Efikasi Diri, Kepribadian dan Peran Faktor Keluarga Terhadap Niat Berwirausaha. Jurnal Manajemen dan Kewirausahaan, 3(3), 751-761.

Kew, J., Herrington, M., Litovsky, Y., \& Gale, H. (2013). Generation Entrepreneur? The State of Global Youth Entrepreneurship. Newcastle: Youth Business International and Global Entrepreneurship. 
Liñan, F., \& Fayolle, A. (2015). A systematic literature review on entrepreneurial intentions: citation, thematic analyses, and research agenda. International Entrepreneurship and Management Journal, 11(4), 907-933.

Liñan, F., Santos, F. J., \& Fernandez, J. (2011). The influence of perceptions on potential entrepreneurs. International Entrepreneurship and Management Journal, 7(3), 373-390.

Ozaralli, N. \& Rivenburgh, N. (2016). Entrepreneurial intention: antecedents to entrepreneurial behavior in the USA and Turkey. Journal of Global Entrepreneurship Research, 6(3), 232.

Santos, F. J., Roomi, M. A., \& Linan, F. (2016). About gender differences and the social environment in the development of entrepreneurial intentions. Journal of Small Business Management, 54(1), 49-66.

Tenenhaus, M. (2004). PLS Regression and PLS Path Modeling for Multiple Table Analysis. COMPSTAT 2004 Proceedings. Würzburg. Berlin.

Wei-Loon, K. (2013). Entrepreneurial orientation and performance of government-linked companies. Journal of Entrepreneurship Management and Innovation, 9(3), 21-41. 